\title{
A modified pH-cycling model to evaluate fluoride effect on enamel demineralization
}

\section{Modelo de ciclagens de pH para avaliar o efeito do fluoreto na desmineralização do esmalte}

\author{
Rosane Maria Orth Argenta* \\ Cinthia Pereira Machado Tabchoury** \\ Jaime Aparecido Cury***
}

\begin{abstract}
Since in vitro $\mathrm{pH}$-cycling models are widely used to study dental caries, they should allow evaluations of fluoride effect on early stages of caries development. Therefore, acid etching on enamel surface must be avoided, enabling surface microhardness (SMH) analysis. In the present study, the pH-cycling model originally described by Featherstone et al. ${ }^{9}$ (1986) was modified to preserve the enamel surface and to produce early carious lesions that could be evaluated using SMH and cross-sectional microhardness (CSMH) measurements. In order to validate this modified model, a dose-response evaluation with fluoride was made. Human enamel blocks with known SMH were submitted to such regimen with the following treatments: distilled deionized water (DDW; control) and solutions containing 70, 140 and $280 \mathrm{ppm}$ F. Data from \%SMH change and $\Delta Z$ (mineral loss) showed a statistically significant negative correlation between $\mathrm{F}$ concentration in treatment solutions and mineral loss. In conclusion, the modified pH-cycling model allowed the evaluation of changes on the outermost enamel layer during caries development, and a dose-response effect of fluoride reducing enamel demineralization was observed.
\end{abstract}

DESCRIPTORS: Dental enamel; Demineralization; Fluorine; Fluorides.

RESUMO: Considerando que os modelos de ciclagens de pH são amplamente usados para estudar a cárie dental, eles deveriam possibilitar a avaliação do efeito do fluoreto nos estágios iniciais do desenvolvimento da cárie. Desse modo, o ataque ácido erosivo na superfície do esmalte deve ser evitado, possibilitando a análise da microdureza de superficie (MDS). No presente estudo, o modelo de ciclagens de $\mathrm{pH}$ descrito por Featherstone et al. ${ }^{9}$ (1986) foi modificado para preservar a superficie do esmalte e para produzir lesões iniciais que pudessem ser avaliadas usando MDS e microdureza do esmalte seccionado longitudinalmente. Para validar esse modelo modificado, uma avaliação dose-resposta a fluoreto foi feita. Blocos de esmalte dental humano de MDS conhecida foram submetidos a tal regime com os seguintes tratamentos: água deionizada (controle) e soluções contendo 70, 140 e 280 ppm F. Os dados de variação de MDS e $\Delta Z$ (perda mineral) mostraram correlações negativas e estatisticamente significativas entre as concentrações de F dos tratamentos e a perda de mineral pelo esmalte. Em conclusão, foi possível avaliar as variações de mineral ocorridas nas camadas mais superficiais do esmalte durante o desenvolvimento de cárie, e um efeito dose-resposta do F reduzindo a desmineralização do esmalte foi observado.

DESCRITORES: Esmalte dentário; Desmineralização; Flúor; Fluoretos.

\section{INTRODUCTION}

Irrespective of the progress in in situ and in vivo experimentation about caries research, in vitro tests are still widely used. A Medline/Biosis search of the last five years revealed over 300 citations documenting in vitro tests associated with caries. Several models were developed, and the present knowledge about the mechanisms of dental caries development, fluoride $(\mathrm{F})$ effect and preventive measures on caries is due mainly to in vitro studies.

Among these models, those mimicking in vitro caries processes ( $\mathrm{pH}$-cycling), as suggested by ten
Cate, Duijsters ${ }^{16}$ (1982), have been used for different purposes ${ }^{18}$; the most important application has been the evaluation of fluoride effect on caries. Different $\mathrm{pH}$-cycling models were developed to evaluate the fluoride effect in either reducing enamel demineralization ${ }^{9}$ or enhancing remineralization ${ }^{17}$. These approaches have been used with tremendous success in cariology.

However, in vitro testing protocols show limitations, and one of them is to be unable to study the effect of fluoride on all stages of the caries process, mainly the early stage. Thus, in the presence of acids an incipient dissolution of the sound enamel

\footnotetext{
*Master Student, Area of Cariology; **Assistant Professor of Biochemistry; ***Professor, Chairman, Area of Biochemistry - School of Dentistry of Piracicaba, State University of Campinas.
} 
Argenta RMO, Tabchoury CPM, Cury JA. A modified pH-cycling model to evaluate fluoride effect on enamel demineralization. Pesqui Odontol Bras 2003;17(3):241-6.

surface occurs, which is followed by the precipitation of less soluble minerals like fluoride in the surface layer ${ }^{13}$. Subsequently, some acids, which remained within the enamel pores, diffuse into inner enamel regions, resulting in the dissolution of the underlying enamel. Mineral components then back diffuse into the surface layer and precipitate in this region. At the same time, a portion of the dissolved ions diffuses out of the enamel surface into the environment. The surface layer appears unaltered because it is continuously regenerated. Thus, the caries process is initiated by a slight dissolution of the enamel surface ${ }^{13}$. Considering the importance of the surface layer in caries progression, the evaluation of changes in this region is relevant and surface microhardness (SMH) measurement is a suitable technique for this purpose.

However, the use of SMH to evaluate the effect of fluoride on early caries lesions is not possible because the $\mathrm{pH}$-cycling models that have been developed up to the present moment promote an acid etching on the enamel surface. When this occurs, the changes on the surface cannot be properly evaluated. According to Zero ${ }^{19}$ (1995), $\mathrm{SMH}$ measurement is a highly sensitive and reproducible method used to evaluate in situ studies. Using $\mathrm{SMH}$ it is possible to study early stages of enamel-dentine demineralization ${ }^{1,4,20,21}$ or enamel remineralization ${ }^{20,22}$. Furthermore, this technique is desirable since it also allows hardness determination in the same substrate before and after the treatments ${ }^{3}$, reducing the experimental error. In addition, White ${ }^{17}$ (1987) found a high correlation $\left(r^{2}=0.94 ; p<0.01\right)$ between the remineralization of early carious lesions measured by SMH and microradiography. Thus, a $\mathrm{pH}$-cycling model that promotes early enamel carious lesion, which may be evaluated by SMH measurement and cross-sectional microhardness (CSMH) measurement at a very close distance from the surface must be proposed.

Thus, an in vitro modified $\mathrm{pH}$-cycling model, allowing the use of $\mathrm{SMH}$ and $\mathrm{CSMH}$ to evaluate the initiation and progression of the caries process, and the study of fluoride effect on enamel demineralization, was developed.

\section{MATERIAL AND METHODS \\ Experimental design}

Enamel blocks (4 x 4 × $2 \mathrm{~mm})$ were prepared from impacted human third molars stored in $2 \%$ formaldehyde solution, $\mathrm{pH}$ 7.0, for at least a month $^{4,17}$. The enamel surface was polished to re- move the outer $50 \mu \mathrm{m}^{11}$. Baseline SMH determination was accomplished using a Future-Tech FM-ARS microhardness tester (Future-Tech Corp., Tokyo, Japan) with a Knoop diamond under 25-g load for $5 \mathrm{~s}$. Five indentations were made at the center of the enamel surface. Enamel blocks with baseline SMH between 360 and 420 KHN (Knoop hardness) were selected for the study. The objectives of baseline SMH determination were to select the blocks and to calculate the SMH change that occurred after $\mathrm{pH}$-cycling.

Thirty-two enamel specimens, with all the surfaces protected with an acid-resistant varnish except for a circular central area of $3.14 \mathrm{~mm}^{2}$, were randomized into 4 treatment groups: distilled and deionized water (DDW; control) and solutions containing 70, 140 and $280 \mathrm{ppm} \mathrm{F}$. These fluoride concentrations correspond to the dilution (1:3) of dentifrices containing 275, 550 and $1100 \mathrm{ppm} \mathrm{F}$ in the oral cavity ${ }^{6}$. All fluoridated solutions were prepared with $\mathrm{NaF}$ and DDW.

\section{pH-cycling regimen}

The $\mathrm{pH}$-cycling model originally described by Featherstone et al. ${ }^{9}$ (1986) was modified by several experiments (data not shown) until establishment of a set of conditions preserving the enamel surface and producing early carious lesions that could be evaluated using $\mathrm{SMH}$ and CSMH measurements. Eight blocks from each group were submitted for 5 days to a $\mathrm{pH}$-cycling regimen. The blocks were kept individually in a demineralizing solution (2.0 mM calcium, $2.0 \mathrm{mM}$ phosphate, $0.030 \mathrm{ppm}$ $\mathrm{F}$, in $75 \mathrm{mM}$ acetate buffer, $\mathrm{pH} 4.3)$ for $3 \mathrm{~h}(20 \mathrm{ml}$ per block), and in a remineralizing solution (1.5 $\mathrm{mM}$ calcium, $0.9 \mathrm{mM}$ phosphate, $150 \mathrm{mM}$ of $\mathrm{KCl}, 0.050 \mathrm{ppm} \mathrm{F}$ in $20 \mathrm{mM}$ cacodylic buffer, $\mathrm{pH}$ 7.4) for $20 \mathrm{~h}$ (10 ml per block) each day. After each cycle, the blocks were returned to the same solutions. This cycle was repeated daily for 5 days and the enamel blocks remained in the remineralizing solution for 2 days until the analyses. Solution treatment was performed twice a day (before and after the demineralizing period) by immersion of the blocks for $5 \mathrm{~min}$ in $10 \mathrm{ml}$ of the solution per block under agitation. The experiment was carried out at $37^{\circ} \mathrm{C}$. De- and remineralizing solutions contained thymol to avoid fungal growth.

\section{Microhardness determination}

After $\mathrm{pH}$-cycling, SMH and CSMH were determined in all enamel blocks. For both determinations, a 25-g load was used for $5 \mathrm{~s}$. For SMH measure- 
Argenta RMO, Tabchoury CPM, Cury JA. A modified pH-cycling model to evaluate fluoride effect on enamel demineralization. Pesqui Odontol Bras 2003;17(3):241-6.

ment, two rows of five adjacent indentations spaced by $100 \mu \mathrm{m}$ were made on both sides of the five baseline indentations. The mean values of the five baseline indentations and the ten measurements after treatments were then averaged within a treatment group and the percentage change of surface microhardness (SMC) was calculated. A 25-g load was used, because in a pilot study it was observed that the 50-g load provoked cracking on the surface of the blocks from the control group. It was also found that the value of KHN at the surface of sound enamel was not statistically different using the 25-g load or the 50-g. Thus, with the lower load it would be possible to find differences between treatments without going beyond the enamel resistance during the penetration of the indenter.

After SMH analysis, all blocks were longitudinally sectioned through the center of the exposed enamel. To measure CSMH, the two halves of each block were embedded in acrylic resin and the cut surfaces were exposed and polished. Three rows of 7 indentations each were made, one in the central region of the dental enamel exposed and the other two $100 \mu \mathrm{m}$ below and above this. The indentations were made at $10 \mu \mathrm{m}$ up to $130 \mu \mathrm{m}$ from the outer enamel surface. The mean values at all 3 measuring points at each distance from the surface were then averaged. CSMH values were converted to mineral content (volume \% mineral) using the relation: mineral content $=4.3(\sqrt{K H N})+11.3^{13}$. The set of data representing each artificial carious lesion (in each enamel block) was curve-fitted. The area under the lesion tracing was calculated by means of the trapezoidal rule (in units of volume percent mineral $\mathrm{x} \mu \mathrm{m}$ ), and subtracted from the normal enamel value to give the parameter $\Delta Z^{8}$. Data of volume \% mineral at each distance from the enamel surface were also presented.

\section{Polarized microscopy analysis}

After CSMH analysis, the embedded enamel half blocks were sectioned in order to obtain a longitudinal section of $100 \mu \mathrm{m}( \pm 10)$. These sections were mounted for examination under a polarizing light microscope at $20 \mathrm{X}$ magnification (DMLSP, Leica, Wetzlar, Germany) after imbibition in deionized water. Digital images were taken with a specific software (Image-Pro Plus, Media Cybernetics, Silver Spring, USA).

\section{Statistical analysis}

Analysis of variance (ANOVA) and Student's paired $t$-test were used to compare surface microhardness before and after the treatments. To show the dose-response effect of fluoride the data of $\% S M C$ and $\Delta Z$ were analyzed by ANOVA and regression. The difference between treatments with regard to baseline SMC and volume \% mineral at each distance from enamel surface were evaluated by the Tukey test. For all statistical analysis, SAS (Software Analyses System) was used and the significance limit was set at $5 \%$.

\section{RESULTS}

Table 1 shows that baseline SMH was not significantly different among the groups. A significant decrease in $\mathrm{SMH}$ was observed after $\mathrm{pH}$-cycling for all treatment groups. A dose-response effect was found between fluoride concentrations in the treatment solutions and \%SMC $\left(\mathrm{R}^{2}=-0.9048\right.$; $\mathrm{p}<0.0001$, linear correlation), and $\Delta \mathrm{Z}$ $\left(R^{2}=-0.9858 ; p=0.0287\right.$, polynomial correlation).

Graph 1 shows that all groups were statistically efficient in reducing the volume \% mineral loss in comparison with the control. It was also shown that a caries lesion of approximately 50-60 $\mu \mathrm{m}$ depth was produced.

TABLE 1 - Surface microhardness of enamel blocks (SMH) before and after pH-cycling, percentage of enamel surface microhardness change (\%SMC) and mineral loss $(\Delta Z)$ according to the treatments $(m e a n \pm s d ; n=8)$.

\begin{tabular}{l|c|c|c|c}
\hline \multicolumn{1}{c|}{ Treatments } & SMH before & SMH after & \%SMC* & $\Delta Z^{* *}$ \\
\hline DDW & $379.4 \pm 20.6 \mathrm{a}, \mathrm{A}$ & $42.0 \pm 28.0 \mathrm{~B}$ & $-89.1 \pm 6.7$ & $1,493.1 \pm 289.9$ \\
\hline $70 \mathrm{ppm} \mathrm{F}$ & $383.7 \pm 32.6 \mathrm{a}, \mathrm{A}$ & $138.5 \pm 36.6 \mathrm{~B}$ & $-63.3 \pm 10.8$ & $660.5 \pm 167.2$ \\
\hline $140 \mathrm{ppm} \mathrm{F}$ & $388.2 \pm 31.9 \mathrm{a}, \mathrm{A}$ & $133.3 \pm 14.0 \mathrm{~B}$ & $-65.5 \pm 3.3$ & $445.1 \pm 259.1$ \\
\hline $280 \mathrm{ppm} \mathrm{F}$ & $372.6 \pm 28.6 \mathrm{a}, \mathrm{A}$ & $234.0 \pm 41.2 \mathrm{~B}$ & $-36.8 \pm 12.0$ & $248.4 \pm 151.8$ \\
\hline \hline
\end{tabular}

DDW: distilled and deionized water.

Means followed by distinct letters are statistically different $(\mathrm{p}<0.05)$. Capital letters show difference between before and after $\mathrm{pH}$-cycling and lower case letters show differences between the treatments. ${ }^{*} \mathrm{R}^{2}=-0.9048 ; \mathrm{p}<0.0001 ;{ }^{* *} \mathrm{R}^{2}=-0.9858 ; \mathrm{p}=0.0287$. 
Argenta RMO, Tabchoury CPM, Cury JA. A modified pH-cycling model to evaluate fluoride effect on enamel demineralization. Pesqui Odontol Bras 2003;17(3):241-6.
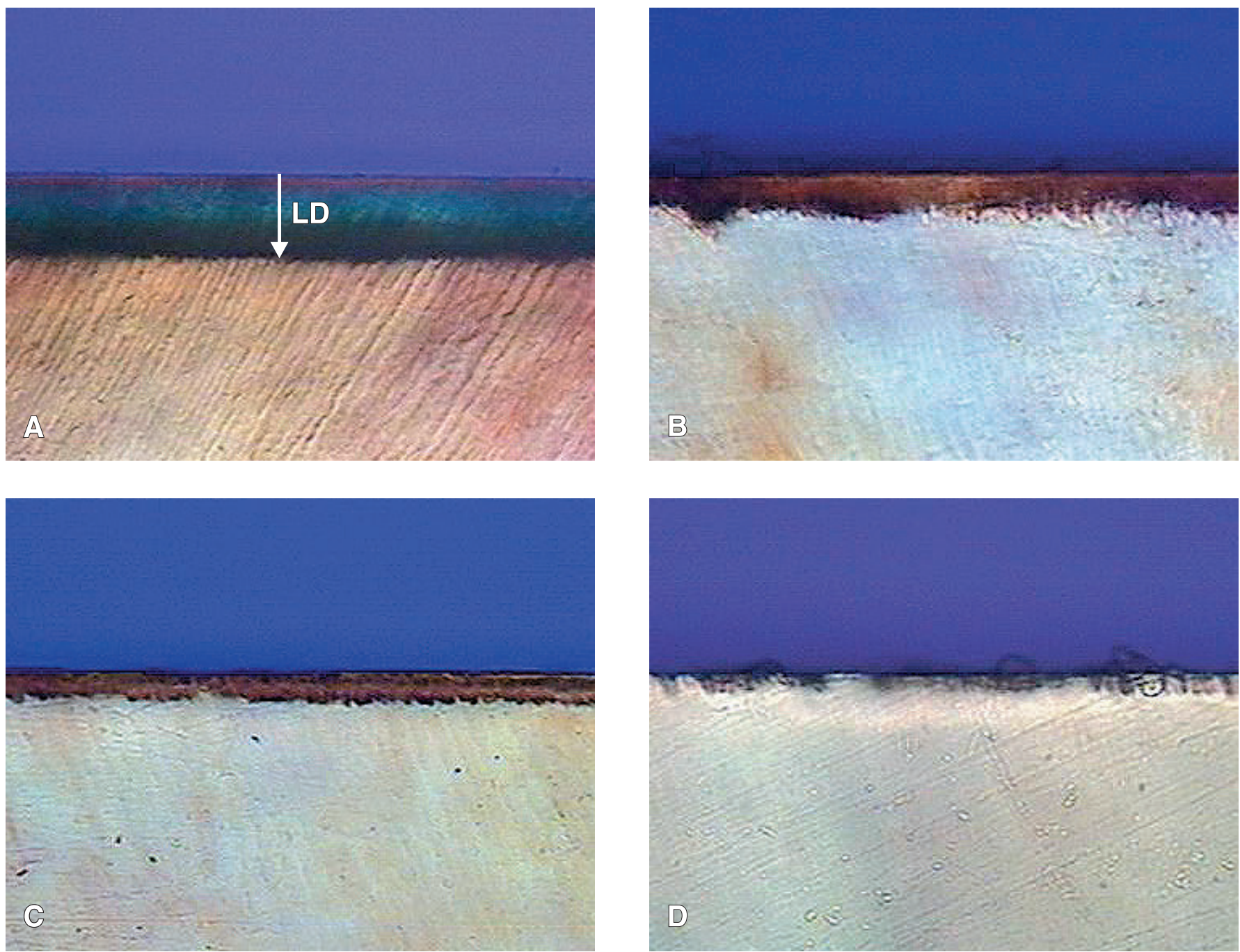

FIGURE 1 - Polarized light microscopy of the caries lesions from the groups control (A) and treated with $\mathrm{F}$ at different concentrations: 70 (B), 140 (C) and 280 (D) ppm. LD = caries lesion depth.

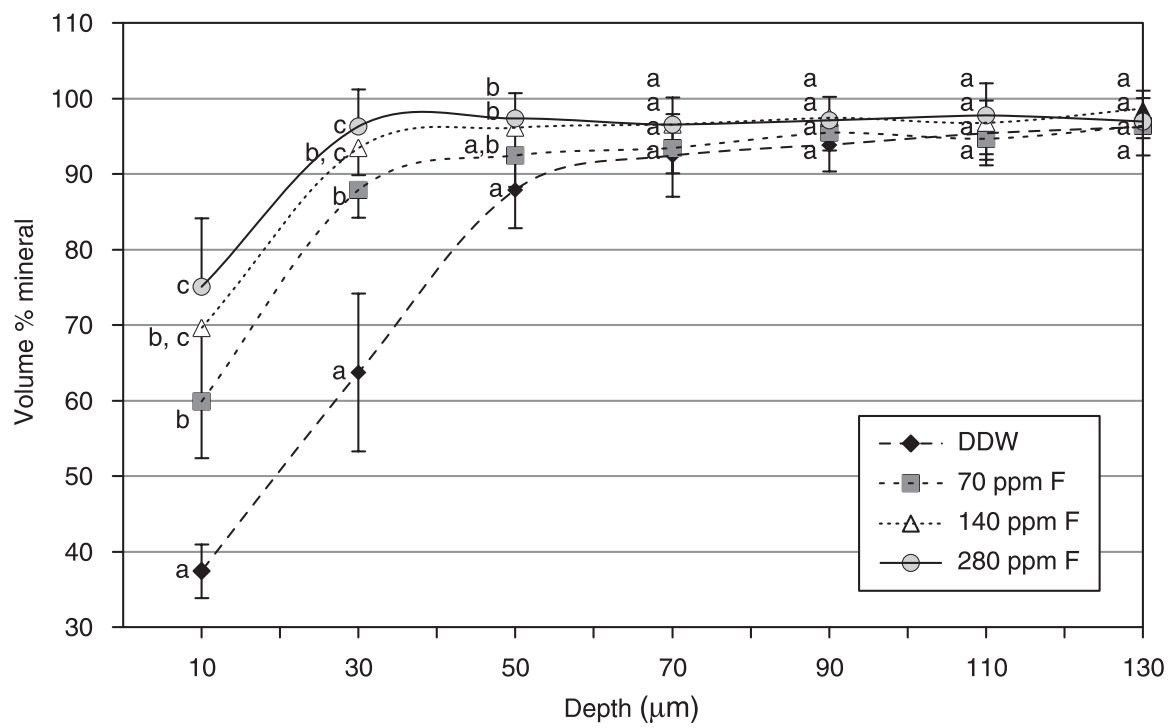

GRAPH 1 - Enamel volume percentage mineral according to the treatments and the distance $(\mu \mathrm{m})$ from the surface. Different letters show statistical significance $(\mathrm{p}<0.05)$ among treatments at each distance from the enamel surface, and bars denote standard deviations. 
Argenta RMO, Tabchoury CPM, Cury JA. A modified pH-cycling model to evaluate fluoride effect on enamel demineralization. Pesqui Odontol Bras 2003;17(3):241-6.

Figure 1 shows typical subsuperficial caries lesions found after the $\mathrm{pH}$-cycling, with preservation of the surface zone. It also shows qualitatively the effect of treatments with $\mathrm{F}$, reducing the depth of the lesions.

\section{DISCUSSION}

For the present pH-cycling model, modified from that described by Featherstone et al. ${ }^{9}$ (1986), some alterations were made. Fluoride was added at low concentrations to the demineralizing and remineralizing solutions. Fluoride in low concentration can be present in the solutions as a contaminant of the reagents used ${ }^{5,15}$. However, the reagents used in the present study did not contain fluoride, which was added to the solutions used and their concentrations were checked with an ion specific electrode. The low fluoride concentrations used $(0.05$ and $0.03 \mathrm{ppm} \mathrm{F})$ did not interfere in the response of the treatments, as can be observed in Table 1, and were relevant for enamel surface preservation (Figure 1, control). The effect of fluoride at low concentrations is well known ${ }^{14}$. Moreover, these concentrations could simulate the remaining fluoride in oral environment after toothbrushing with fluoridated dentifrices and even that found in saliva due to the regular use of fluoridated water. In addition, the $\mathrm{pH}$ of the remineralizing solution was raised, and at 7.4 we observed the best conditions for preserving the enamel surface.

In the present study, the demineralization period lasted for 3 hours per day and the total duration of the regimen was 7 days. According to ten Cate, Duijsters ${ }^{16}$ (1982), this demineralization period simulates a low cariogenic challenge. However, a $60 \%$ volume mineral loss was observed in the DDW group at $10 \mu \mathrm{m}$ from the enamel surface (Graph 1). In addition, the lesion depth is similar to that found in vitro by Featherstone et al. ${ }^{9}$ (1986), whose study showed a correlation with clinical data of caries development. Therefore, after a one-week treatment, it was possible to evaluate $\mathrm{SMH}$ and $\mathrm{CSMH}$ at very close distances from the surface. This fact supports the effectiveness of this modified model in simulating early carious lesions and in studying the initiation and progression of the caries process. It should be emphasized that keeping the enamel blocks in the remineralizing solution for additional 2 days after the 5 days of $\mathrm{pH}$-cycling is relevant to preserve the enamel surface layer allowing the SMH determination.

In order to validate this modified model and to mimic the use of fluoridated dentifrices, a dose- response evaluation was made. Data from \%SMC and $\Delta Z$ (Table 1 ) showed a statistically significant negative correlation between the concentration of fluoride in treatment solutions and mineral loss. This suggests that the $\mathrm{pH}$-cycling model proposed is adequate for studying in vitro fluoride treatments in early enamel lesions.

It is clearly established that the major interactions of hard tissue substrate with the oral environment occur at the surface layer of the sample. This effect is also observed with fluoride, which reacts with dental tissues at the most superficial layers ${ }^{12}$. Thus, the evaluation of early surface changes in dental enamel seems to be sensitive for measuring the fluoride efficacy and may present the greatest predictive value with respect to anti-caries effectiveness ${ }^{19}$. Additionally, the $\mathrm{pH}$-cycling models developed up to the present are limited to the study of the changes in the subsurface region and cannot accurately evaluate changes occurring in the outer $25 \mu \mathrm{m}$ of surface enamel ${ }^{2,7}$. Thus, data suggest that the modified $\mathrm{pH}$-cycling model is suitable for evaluating these changes near the enamel surface.

Another modification made was the use of 25-g load instead of 50-g load, which has been currently used to evaluate $\mathrm{SMH}^{19}$. In the present study, a 25-g load was tested and greatly increased the sensitivity of the method allowing the determination of $\mathrm{SMH}$ even when the cariogenic challenge was severe.

In summary, the modified pH-cycling model allowed the evaluation of changes on the outermost enamel layer during caries development and, in addition, a dose-response effect of fluoride reducing enamel demineralization was observed.

\section{ACKNOWLEDGMENTS}

We thank FAPESP (Fundação de Amparo à Pesquisa do Estado de São Paulo) for the scholarship (Proc. no. 99/12229-3) and financial support (Proc. no. 01/00722-9) provided for this research. The skillful technical assistance of Mariza J. C. Soares and Waldomiro V. Filho is gratefully acknowledged. The authors thank Prof. Dr. Glaucia Maria Bovi Ambrosano for the statistical analysis and Dr. Anderson T. Hara for the analysis of polarized microscopy. This publication was based on a thesis submitted, by the first author, to the School of Dentistry of Piracicaba, University of Campinas, as fulfillment of the requirements for obtaining a MS degree in dentistry (concentration in cariology). 
Argenta RMO, Tabchoury CPM, Cury JA. A modified pH-cycling model to evaluate fluoride effect on enamel demineralization. Pesqui Odontol Bras 2003;17(3):241-6.

\section{REFERENCES}

1. Aires CP, Tabchoury CPM, Del Bel Cury AA, Cury JA. Effect of a lactose-containing sweetener on root dentine demineralization in situ. Caries Res 2002;36:167-9.

2. Arends J, ten Bosch JJ. Demineralization and remineralization evaluation techniques. J Dent Res 1992; 71 (special issue):924-8.

3. Arends J, Schuthof J, Jongebloed WG. Lesion depth and microhardness indentations on artificial white spot lesions. Caries Res 1980;14:190-5.

4. Cury JA, Rebelo MAB, Del Bel Cury AA, Derbyshire MTVC, Tabchoury CPM. Biochemical composition and cariogenicity of dental plaque formed in the presence of sucrose or glucose and fructose. Caries Res 2000;34:491-7.

5. Delbem ACB, Cury JA. Effect of application time of APF and $\mathrm{NaF}$ gels on microhardness and fluoride uptake of in vitro enamel caries. Am J Dent 2002;15:169-72.

6. Duke SA, Forward GC. The conditions occurring in vivo when brushing with toothpastes. $\mathrm{Br}$ Dent J 1982; 152:52-4.

7. Featherstone JDB. Consensus conference on intra-oral models: evaluation techniques. J Dent Res 1992;71(special issue):955-6.

8. Featherstone JDB, Shariati M, Brugler S, Fu J, White DJ. Effect of an anticalculus dentifrice on lesion progression under $\mathrm{pH}$ cycling conditions in vitro. Caries Res 1988; 22:337-41

9. Featherstone JDB, O'Reilly MM, Shariati M, Brugler S. Enhancement of remineralization in vitro and in vivo. In: Leach SA. Factors affecting de- and remineralization of the teeth. Oxford: IRL Press; 1986. p. 23-34.

10. Featherstone JDB, ten Cate JM, Shariati M, Arends J. Comparison of artificial caries-like lesions by quantitative microradiography and microhardness profiles. Caries Res 1983;17:385-91.

11. Featherstone JDB, Zero DT. An in situ model for simultaneous assessment of inhibition of demineralization and en- hancement of remineralization. J Dent Res 1992;71(special issue):804-10.

12. Ijima Y, Koulourides T. Fluoride incorporation into and retention in remineralized enamel. J Dent Res 1989; 68:1289-92.

13. Margolis HC, Moreno EC. Physicochemical perspectives on the cariostatic mechanisms of systemic and topical fluorides. J Dent Res 1990;69(special issue):606-13.

14. ten Cate JM. Review on fluoride, with special emphasis on calcium fluoride mechanisms in caries prevention. Eur J Oral Sci 1997;105:461-5.

15. ten Cate JM, Timmer K, Shariati M, Featherstone JDB. Effect of timing of fluoride treatment on enamel de- and remineralization in vitro: a pH-cycling study. Caries Res 1988;22:20-6.

16. ten Cate JM, Duijsters PPE. Alternating demineralization and remineralization of artificial enamel lesions. Caries Res 1982;16:201-10.

17. White DJ. Reactivity of fluoride dentifrices with artificial caries. Caries Res 1987;21:126-40.

18. White DJ. The application of in vitro models to research on demineralization and remineralization of the teeth. Adv Dent Res 1995;9:175-93.

19. Zero DT. In situ caries models. Adv Dent Res 1995; 9:214-30.

20. Zero DT, Featherstone JDB, Fu J, Hayes AL, Vogel GM. Response of a de/remineralization in situ model to fluoride dentifrice [abstract]. Caries Res 1994a;28:208.

21. Zero DT, Fu J, Anne KM, Cassata S, McCormack SM, Gwinner LM. An improved intra-oral enamel demineralization test model for the study of dental caries. J Dent Res 1992; 71(special issue):871-8.

22. Zero DT, Fu J, Scott-Anne K, Proskin H. Evaluation of fluoride dentifrices using a short-term intra-oral remineralization model [abstract]. J Dent Res 1994b; 73:272. 